\title{
Factors Affecting Secondary School Principals’ Time Management Practices in Khyber Pakhtunkhwa
}

\author{
Iqbal Amin Khan ${ }^{*}$ \\ Umar Ali Khan ${ }^{* *}$ \\ Abdur Rashid ${ }^{* * *}$
}

\begin{abstract}
This study sought to investigate whether principal's age, gender, administrative experience, training in time management area, school's nature, level, location and complexity has any effect on the time management practices. Six time management practices used by secondary school principals i.e. scheduling contacts, managing meetings, delegating tasks, setting priorities, managing paperwork, handling interruptions were incorporated in a questionnaire. A questionnaire was designed, validated and administered to respondents for collecting data having Cronbach Alpha value of 0.864. Data were collected from 344 secondary school principals selected through stratified random sample from seven divisional headquarter districts of Khyber Pakhtunkhwa. Results show that principal's administrative experience and school's level have significant effect on principals' time management practices. Whereas principal's age, gender, training in time management area, school's nature, location and complexity have no significant effect on principals' time management practices. It was recommended that introductory courses, refresher courses, workshops, and seminars on time management practices should be included in in-service training program for principals to equip them with skills, knowledge and attitude on adequate time management practices regardless of their personal characteristics and school's level, location, nature and complexity.
\end{abstract}

* Ph. D Scholar, Institute of Education \& Research, Gomal University Dera Ismaial Khan \& Lecturer in Department of Education, University of Malakand, Dir Lower

** Dean \& Director, Institute of Education \& Research, Gomal University Dera Ismaial Khan

*** Lecturer in Education, Shaheed Benazir Bhutto University, Sheringal, Dir Upper 
Keywords: Time management practices, principals' age, principals' gender, School's nature, School's complexity

\section{Introduction}

Time is a unique and scarcest resource of the universe, which cannot be replaced, accumulated, turned on and off and stocked like raw material. It passes at pre-determined rate and equally distributed to all human being. Therefore this scare resource should be managed efficiently and used wisely (Ojo and Olaniyan 2008; p. 127-133). According to Covey (2009:12) time is "one of our most valuable resources in the modern world." School principals' working day is chaotic, filled with regular problems and interruptions that have needs concentration (Blendinger \& Snipes, 1996; Hallinger \& Murphy, 2013). School principals are frequently called on to meet students' parents or deal with parental concerns (Miller, 2001). Principals use great part of their day in unplanned and planned meetings and on implementation of administrative responsibilities (Horng, Klasik, \& Loeb, 2010). Similarly, Manasse (1985) mentioned that "The nature and pace of events often appear to control principals rather than the other way around.” (p. 442). In fact, Hallinger and Murphy (2013) recognize that finding time to perform multifarious tasks is one of the greatest challenges of leadership for school improvement in the principals' job. Covey (2009) unambiguously states that: "Effective people usually have effective time management skills. People who routinely use time management techniques are the highest achievers in all walks of life and learning to use these skills well enables one to function effectively, even under pressure".

The administrative procedure is multifaceted and challenging with constant change, high testing, dealing with public and a numerous responsibilities both planned and unplanned (e.g. meetings, phone calls, discipline, email). Therefore, it is necessary that school principals should plan their lives and discover ways to manage their time effectively and efficiently (Hager, 2006). Similarly, Tracy (2004) found that people are bounded to others and situations that waste time and weaken the efficiency all daytime long.

Though school principals have many responsibilities yet the researchers in the field of administration generally and in educational administration particularly find that this topic has not received great attention. Only few research studies have paid attention to secondary 
school principals in the last three decades and the available literature has suggested that school principals need help in recognizing time management practices for becoming successful educational managers and leaders (e.g., Grissom, Loeb, \& Master, 2013; Spillane \& Hunt, 2010; Goldring, Huff, May, \& Camburn,.. 2008; Horng, Klasik, \& Loeb, 2010; Spillane, Camburn, \& Pareja, 2007; Kennedy, 2002).

Halinger and Murphy (2013) and Marshall (2004) were of the view that size and structural complexity of the school should be taken into account when principals of the schools look for to put their educational proficiency into reality. Akomolafe (2005) found that enrolment of students in school is not a significant issue in managing time by school leaders. Moreover, he found that school with low, medium or high students' enrolment has no significant effect on principals' time management. Edoreh (1989) also found that students' enrolment has no significant effect on allocation of time to task by principals. On the other hand, Allison and Mortiff (1994) found that students' enrolment in school can be a predictor of utilization of time by school administrators. Burke (1980) argued that school size to be predictor of time use by school principals. Slaven and Totterdell (1993), Van Eerde (2003) and Green and Skinner (2005) have suggested that organizations should invest in time management training in order to improve workers knowledge about time management strategies and skill in their execution. Botha (2013) argued that "both male and female school principals require improving their time management practices by determining how they currently spend their time, and then begin to change the way they manage themselves in relation to time". The way through which school principals utilize their time can possibly rely on such characteristics as level (secondary or Higher secondary), locality (urban or rural), school type (Government or private), complexity of school, principals' time management training, years of administrative experience, and principals' gender.

\section{Literature Review}

Literature on time management suggest that one of the main factors which are responsible for school principals' ineffectiveness and inefficiency is lack of time management skills and abilities. The way secondary school principals manage their time and use it efficiently and effectively is of supreme importance to the success of the school that 
they manage (Botha, 2013). Therefore at the end of each day, some individuals achieve more than others because the achievements of successful people and others in generally is mainly based on their ability to manage their given time effectively and efficiently. Covey (2009) thus rightly said that effective people usually have effective time management skills. Individuals who regularly use time management strategies effectively and efficiently are the highest achievers in all walks of life and learning to these skills enables one to work effectively, even under pressure. Claessens, Van Earde, Ruttee, and Roe (2007:361) recommended that "there is a need for more rigorous research into the mechanism of time management and the factors to contribute to its effectiveness. The ways in which stable time management behaviours can be established also deserve further investigation."

Horng et al., (2010) found that school principals spent approximately $20 \%$ of their time in transition between the tasks. Principals spent $54 \%$ of their time in the school office and another 9\% elsewhere in the main school office. About $40 \%$ of principals' time was spent away in observing teachers and students in playgrounds, classrooms, and in halls. On average, the principals spent only $8 \%$ of the school day in classrooms. They spent even less time, approximately 4\%, off the school entirely.

Different time management strategies to enhance time management including setting realistic goals, prioritizing, and optimizing planning, involving a team, problem-solving barriers, and early management of potential distractions can facilitate to maintain focus on tasks (Chase et al., 2013). Continuous evaluation of the effectiveness of time management strategies allows school principals to identify areas of improvement and recognize progress. It also emphasized that proper time management facilitates qualitative teaching and learning, in accomplishing educational goals and objectives. Mullins (2005, p.265) points out that "whatever, the attributes or qualities of successful managers are, or the qualities of subordinate staff are, one essential underlying criterion is the effective use of time." Schriber and Gutek (1987) identified nine important temporal dimensions which might be primarily facilitated by employees time management competencies and related personality dimensions (punctuality; procrastination avoidance; awareness of time use and planning; temporal prioritizing of tasks; accurate allocation of time; staying on schedule; meeting deadlines; synchronization and coordination; and autonomy of time use) and these are the positive actual outcomes. 
Previous researches and many books propose that individual can utilize time efficiently and efficiently by setting long-term and short-term goals, keeping time logs, making to-do lists, prioritizing tasks, scheduling, and organizing individual's workspace (Claessens et al., 2007; Macan, 1994). Britton and Tesser (1991) mentioned three characteristics of time management: long-range planning, short-range planning, and time attitudes. In the same way, Macan (1994) acknowledged three components of time management: setting priorities and goals, mechanics (i.e., making lists and scheduling), and preference for organization. Robertson (1999) identified six practices through which school' principals manage their day-to-day school activities. These were scheduling contacts, delegating, managing meetings, handling interruptions, managing paperwork and establishing priorities.

Kaufman (2004) mentions that constantly late individuals do not manage their time plan appropriately. It is recommended that being well planned is a main asset to being successful at working in a fruitful and efficient way. Factors that direct to efficient time management comprise good organization, having time schedules and files and setting up a practice of study (Swart, Lombard, \& Jager, 2010). However schedule necessitate to be prioritized (Mancini, 2003) and be set aside under constant surveillance to keep away from slippages (Bittel, 1991). McCuen (1996) verifies that scheduling is one practice specified for managing time, which can reduce the propensity to procrastinate. A schedule or 'time planner' ought to be prepared according to priority, in the shape of a daily 'to-do list' or checklist of what still desires to be done (Forsyth, 1994; Amos, 1998; Swart et al., 2010).

One of the primary keys to good organization is planning (Forsyth, 1994; Tracy, 2004) and a well outlined schedule (Amos, 1998; Swart et al, 2010). Tracy (2014) suggests a series of techniques for managing time: making written plans, create daily "to-do" list, set clear priorities, stay on track, determining key result areas, delegate to others, concentrate single-mindedly, overcome procrastination, control interruptions, manage the telephone and conducting effective meetings. Gordan and Borken (2014) have mentioned that effective time management strategies can be separated into four distinct principles. These are short and long-term goals, selecting priorities among competing responsibilities, planning and organizing activities, and minimizing time wasters. Kearns and Gardiner (2007) have identified four main behaviours of highly effective people on the basis of their experiences and courses conducted in time management field. These include, having a clear purpose in career, planning and prioritizing, 
avoiding interruptions and distractions and being organized. Amos (1998) and Tracy (2004) also suggest a filing system be employed as an effective time management tool. Individuals need to determine the time of day that they are most likely to be productive, alert and energetic (Bittel, 1991; Mancini, 2003; Tracy, 2004). Training in time management results in an increased use of time management behaviours, which in turn led to more positive outcomes (Hall \& Hursch, 1982). However (Macan, 1994) found that time management training was not found to be effective. Moreover, school size and structural complexity must also be taken into account when principals seek to put their educational expertise into practice (Marshall, 2004; Halinger \& Murphy, 2013).

Most of the research articles and literature on time management give hundreds of practices to make principals and other executives more efficient in using their time to get more things done efficiently and effectively. However in this research we identified six time management practices used in academic and non-academic institutions based on time management literature and on our personal experiences. These were:

1. Practices for scheduling contacts (planning and scheduling)

2. Practices for managing meetings

3. Practices for delegating tasks

4. Practices for managing paperwork

5. Practices for establishing priorities and

6. Practices for handling interruptions

The first practice scheduling contacts, includes being clear about schedule time, in other words a finishing time and as well as a starting time of a task. Always plan and schedule activities and try to strict to them according to the diary, planner chart or calendar in accomplishing educational goals and objectives (Kaufman, 2004; Macan, 1994; Claessens et al., 2007; Britton and Tesser, 1991; Gordan \& Borken 2014). The second practice, managing meetings, includes how to conduct effective meetings, having clear agenda, time a meeting takes and the dynamics within the meeting (Robertson, 1999; Chase et al., 2013; \& Tracy, 2014). Third practice, delegating tasks, includes delegation of tasks to subordinates based on principle 'right person for the right job', how delegation has worked and how we can develop people at workplace and having a system for monitoring and measuring performance (Akomolafe, 2005; Akomolafe; 2011; Tracy, 2014; \& Robertson, 1999). The fourth practice, managing paperwork, includes minimizing the 
volume of paper on the tidy desk, responding quickly to letters, memos, faxes, reports, forms, proposals and having an efficient filing system (Akomolafe \& Oluwatimehim, 2013; Gordan \& Borken 2014; \& Robertson, 1999; Glodt, 2006). The fifth practice, establishing priorities, includes tasks such as setting aside time each day to plan out the day, week, and month's tasks and prioritize them by making lists on the urgency basis and setting deadlines (Gorman, 1993; Macan, 1994; Claessens et al, 2007; Kearns \& Gardiner, 2007; Chase et al, 2013; Gordan \& Borken, 2014). The final practice is handling interruptions. The academic setting for both academic and general staff provides plentiful opportunities for interruptions and distractions, for example, student demands, visitors, emails, phone or mobile calls, and colleagues who just want a minute of your time (Kearns \& Gardiner, 2007; Chase et al., 2013; Gordan \& Borken 2014; Tracy, 2014).

In a school, the role of the principal is of utmost significance. Therefore, principals require efficient and effective time management abilities to perform all the activities smoothly in school. Only a very few studies have been conducted on the time management strategies of school principals internationally and suggested that school principals need assistance in identifying practices for becoming successful educational managers and leaders (Shelenger \& Roesh, 1989; Hill, 1998; Robertson, 1999; Larry, 2003; Forster, 2006; Aquila, 2007; Moorosi, 2007; Kettler, 2007; Grissom et al, 2013; Spillane \& Hunt, 2010; Horng et al, 2010; Goldring et al., 2008; Spillane, Camburn, \& Pareja, 2007; Larry, 2004; Kennedy, 2002; Edwards, 1990) but none of the studies, to the best of our knowledge, have tried to unearth the principals' time management practices and to discover whether principals' age, principals' gender, principals' years of administrative experience, school's type (Government or private), school's level (secondary or Higher secondary), school's locality (urban or rural), and school's complexity has any effect on principals' time management practices in Pakistani context. This current study is an attempt to fill that gap.

\section{Statement of the Problem}

The present study aimed to explore whether principal's age, gender, experience, training in time management areas, and school's level, type, locality, complexity (students enrollment, number of teaching staff and support personnel, number of summative evaluation and number of staff 
requiring extra paper work) has any effect on principals' time management practices.

\section{Objectives}

Following were the objectives of the study:

1. To investigate the effect of principal's age, principal's gender; principal's administrative experience; principal's training in time management area on principal's time management practices.

2. To investigate the effect of school's nature; school's level; school's location and school's complexity on principal's time management practices.

\section{Significance}

This study is important examining those practices that help principals manage their time in such a way as to keep them focused on more important tasks. The managerial work of principals is of importance because they put efforts in mobilizing and motivating employees running the institution throughout the various stages of planning, organizing, directing and controlling its activities. Consideration of principals utilizing time effectively for managerial and professional tasks has not received much attention, until recently. Time management is a subject which is basic to job performance.

This research study aimed contribute to knowledge on the need for schools' administrator to set priorities on routine school actions, and that school enrolment and locality would not hinder time management practices of principals. It could be a significant feature for students' academic achievement if school managers are conscious of careful use of time, more time could be owed to academic and non-academic activities. Teachers' use of their time could be improved if school management engages prudent make use of time in school activities. This research is a valuable work out and there is no doubt that it would not only be of assistance to school community but also to general readers.

\section{Research Questions}

For the achievement of the objectives following research questions were formulated.

1. To study whether principal's age, principal's gender; principal's administrative experience; and principal's training in time management area have any effect on principal's time management practices? 
2. To study whether school's nature; school's level; school's location and school's complexity have any effect on principal's time management practices?

\section{Methodology}

The nature of this research study was descriptive and survey research design was used for gathering data from the field.

\section{Population}

Pakistan is comprised of five provinces i.e. Sindh, Punjab, Khyber Pakhtunkhwa, Baluchistan, and Gilgit Baltistan. These provinces are further administratively sub-divided into Divisions, districts and tehsils. Khyber Pakhtunkhwa which was formerly known as North-West Frontier Province (N-W.F.P) is one of the five provinces of Pakistan. This province is further administratively divided into seven divisions (Kohat, Dera Ismaial Khan, Peshawar, Hazara, Malakand, Bannu and Mardan) and twenty five districts. 1485 government and private secondary schools are located in these seven divisional headquarter districts in which 1485 permanent/acting school principals are serving (Source: Statistical Booklet on Elementary \& Secondary Education Department; Khyber Pakhtunkhwa, 2009-10).

\section{Sample}

Sample was selected from seven districts of Khyber Pakhtunkhwa. The sampled divisional headquarter districts were selected purposively. Each sampled district was treated as a stratum. Since the districts (strata) were spread geographically, the sample was representative of the population. $25 \%$ secondary school principals were proportionally selected from each sample district by school's nature wise, location wise and gender wise. The sample for this study consisted of 372 secondary schools (184 Government and 188 Private), with due representation from all the seven districts. The composition of the sample were 311 secondary and 61 higher secondary school principals; of these 248 were male and 124 were female principals; 184 were Government and 188 were Private school principals; and 181 school principals were working in urban areas whereas 191 were working in rural areas. 
Of the 280 respondents, 38.2 percent were between the age group of 25 and 40 years, 18.9 percent were between 41 to 45 years, 16.8 percent were between 46 to 50 years; 18.2 percent were between 50 to 55 years and 7.9 percent were over 55 years (Table 1). 66.7 percent of the respondents were male and 33.3 percent were female. The relatively low level of female participation could be attributed to a number of issues, including cultural aspects as well as lack of awareness of the importance of research benefits to society.

157 principals (56.03\%) got training in time management areas while 123 principals (43.93\%) did not get any training. This implies that a significant numbers of the participants did not have an opportunity of training in time management areas. $78.21 \%$ principals were from secondary schools while $21.79 \%$ participants were from higher secondary schools indicating that higher secondary schools were comparatively few. $51.42 \%$ principals were from rural areas where as 48. $58 \%$ respondents were from urban areas, indicating that most government schools are situated in rural areas and that more private schools are located in urban areas. 140 (50\%) secondary school principals were from government sector and same numbers of school principals were from privately managed school.

Forty principals (14.3\%) were newly appointed principals with less than a year of experience. 104 principals (37.1\%) were new to the administration level with less than five years experience. This implies that a significant numbers of participant were appointed on this post, either as fresh graduates, which would give details high number of young principals, or may be promoted to this post. Sixty three principals (22.5\%) with less than 10 years of experience and seventy three principals (26.1\%) relatively low number of principals with over 10 years of experience may be due to principals having retired in old age.

One hundred twenty one (43.2\%) school principals opined that in their schools less than 400 students were enrolled. 102 (36.4\%) secondary school principals believed that between 400-800 students were enrolled in their schools. 33 (11.8\%) confirmed that between 800-1200 students were enrolled in their schools and 24 (8.6\%) school principals said that more than 1200 students were enrolled in their schools. 162 (57.9\%) principals opined that in their schools age range of students were found to be $10-16$ years and 118 (42.1\%) school principals believed that age range of students in their schools were 10-18 years. Out of the 280 secondary school principals, $146(52.1 \%)$ revealed that less than 20 teachers were working in their schools, 104 (37.1\%) believed that 20-40 school teachers were working in their schools, 24 (8.6\%) school 
principals opined that 41-60 teachers were working in their schools, 03 (1.1\%) secondary school principals opined that 61-80 teachers were teaching in their schools and $03(1.1 \%)$ school principals were of the view that less than 100 teachers were working in their schools.

Table 1

Sample profile characteristics

\begin{tabular}{lcc}
\hline Variables & Frequency & Percentage \\
\hline Age (Years) & 107 & 38.2 \\
Less than 40 & 53 & 18.9 \\
$41-45$ & 47 & 16.8 \\
$46-50$ & 51 & 18.2 \\
$51-55$ & 22 & 7.9 \\
Greater than 55 & & \\
\hline Gender & 187 & 66.78 \\
Male & 93 & 33.22 \\
Female & & \\
\hline Training in Time Management & 157 & 56.07 \\
Yes & 123 & 43.93 \\
No & & \\
\hline Level of School & 219 & 78.21 \\
Secondary & 61 & 21.79 \\
Higher Secondary & & \\
\hline Locality of School & 144 & 51.42 \\
Rural & 136 & 48.58 \\
Urban & & \\
\hline Type of School & 140 & 50.00 \\
Government & 140 & 50.00 \\
Private & & \\
\hline Length of Experience (As Principal) & 40 & 22.5 \\
Less than a year & 104 & \\
Less than 5 years & 63 & \\
Less than 10 years & 73 & \\
Greater than 10 years & & \\
\hline School's Complexity & & \\
\hline
\end{tabular}




\begin{tabular}{lcc}
\hline Enrollment in school & & \\
Less than 400 & 121 & 43.2 \\
$400-800$ & 102 & 36.4 \\
$800-1200$ & 33 & 11.8 \\
Greater than 1200 & 24 & 8.6 \\
Age Range of Students & & \\
10-16 Years & 162 & 57.9 \\
10-18 Years & 118 & 42.1 \\
Number of Staff principal's Supervises & & \\
Teachers & & \\
Less than 10 & 20 & 7.1 \\
11-20 & 40 & 14.3 \\
21-30 & 60 & 21.4 \\
31-40 & 80 & 28.6 \\
$41-50$ & 50 & 17.9 \\
$51-70$ & 30 & 10.7 \\
\hline
\end{tabular}

\section{Construction of Research Instrument}

A survey questionnaire was developed for gathering data pertaining to demographic variables (gender, age, training in time management area, length of experience, nature of school, level of school; locality of school and complexity of school) and different time management practices. Thirteen statements fall under practices for scheduling contacts, nine fall under practices for managing meetings, twelve fall under practices for delegation, nine fall under practices for managing paperwork, eleven fall under practices for establishing priorities and thirteen fall under practices for handling interruptions.

For validity of the instrument, initially an items-bank of 82 items was created. After initial construction, it was shown to a panel of experts. These people had sufficient experience in teaching and knowledge of the field of Educational Leadership, Administration and Management studies. Four of these experts were professors holding Ph.-D degree in Educational Management; six were assistant professors holding Ph.-D degrees in Educational Leadership, teaching at the M.-Ed and B.-Ed levels and two were principals of Regional Institute of Teacher Education (RITE), ten were secondary school principals and two were 
language teachers who were teaching in the schools. The first author personally held meetings with these experts and discussed the questionnaire. The experts were asked to write comments for and suggest improvement regarding ambiguity in the instruction, clarity, design and nature of the questions in the questionnaire on a white paper. Their valuable suggestions were incorporated in the questionnaire.

After pre-testing, the refined and modified questionnaire consisting of 67 Likert-type items were pilot tested on thirty school principals to check accuracy of the instrument; the response was satisfactory. Of the 372 distributed questionnaires, 280 usable and completed questionnaires were received, with a response rate of 75.26 percent. The response rates for every type of school were: government 51.42 percent $(n=144)$ and for privately managed 48.58 percent $(n=136)$.

Table 2

Reliability of the Questionnaire

\begin{tabular}{lcc}
\hline \multicolumn{1}{c}{$\begin{array}{c}\text { Time Management } \\
\text { Practices }\end{array}$} & $\begin{array}{c}\text { Number of items in each } \\
\text { category }\end{array}$ & $\begin{array}{c}\text { Cronbach's } \\
\text { Alpha }\end{array}$ \\
\hline Scheduling contacts & 13 & 0.846 \\
Managing Meetings & 09 & 0.843 \\
Delegating practices & 12 & 0.889 \\
Managing Paperwork & 09 & 0.867 \\
Establishing Priorities & 11 & 0.888 \\
Handling Interruptions & 13 & 0.851 \\
Total & 67 & 0.864 \\
\hline
\end{tabular}

Cronbach alpha calculated for the questionnaire regarding subcategories of time management practices i.e. practices scheduling contacts, managing meetings, delegation, establishing priorities and handling interruptions for the secondary school principals were (.846, $.843, .889, .867, .888$, and .851 ) respectively.

\section{Results}

The aim of this research was to investigate principals' time management practices and to identify if the nature, type and locality of school, had any effect on this. 
Table 3

Results for overall principals' time management practices by Level of School, Type of school and Locality of school

\begin{tabular}{llllll}
\hline Level of school & $\mathrm{N}$ & Mean & $\mathrm{S} . \mathrm{D}$ & $\mathrm{t}$ & $\mathrm{S}$ Sig (2-tailed) \\
\hline Secondary & 219 & 3.60 & .653 & 4.38 & .000 \\
$\begin{array}{l}\text { Higher Secondary } \\
\text { Type of school }\end{array}$ & 61 & 3.92 & .638 & & \\
$\begin{array}{l}\text { Government } \\
\text { Private }\end{array}$ & 140 & 3.73 & .505 & 0.246 & .806 \\
$\begin{array}{l}\text { Locality of school } \\
\text { Urban }\end{array}$ & 140 & 3.71 & .689 & & \\
Rural & 140 & 3.71 & .652 & .228 & .820 \\
Note: $\mathrm{p}<.05$ & 140 & 3.73 & .550 & & \\
& & & & &
\end{tabular}

The mean principals' time management practices scores by nature of school were: secondary (3.60) and higher secondary (3.92); Government (3.73) and Private (3.71); and Urban (3.71) and Rural (3.73). There is a difference between principals' time management practices scores of principals working in the different levels of school. However, further analysis was required as the statistical significance of the differences is unknown. Consequently t-test was performed. The results reveal a significant difference between the mean scores of the different levels of school as a significance score less than .05 (.000). Similarly, mean principals' time management practices scores by type of school and locality of school were found non-significant.

Table 4

Multiple Linear Regression Model - 1 for time management practices Based on secondary school principals’ Perceptions

\begin{tabular}{|c|c|c|c|c|c|}
\hline \multirow{2}{*}{ Model } & \multicolumn{2}{|c|}{$\begin{array}{l}\text { Un-standardized } \\
\text { Coefficients }\end{array}$} & \multirow{2}{*}{$\begin{array}{l}\text { Standardized } \\
\text { Coefficients } \\
\text { Beta }(\beta)\end{array}$} & & \multirow{2}{*}{ Sig. } \\
\hline & B & $\begin{array}{l}\text { Std. } \\
\text { Error }\end{array}$ & & & \\
\hline (Constant) & 2.805 & .317 & & 8.859 & .000 \\
\hline Age of principal & .062 & .035 & .139 & 1.737 & .084 \\
\hline Gender of principal & .054 & .071 & .045 & .766 & .444 \\
\hline Years of experience & .097 & .043 & .164 & 2.251 & .025 \\
\hline $\begin{array}{l}\text { Time management } \\
\text { training }\end{array}$ & .097 & .071 & .081 & 1.361 & .175 \\
\hline Type of school & .090 & .082 & .075 & 1.093 & .275 \\
\hline Level of school & .258 & .081 & .207 & 3.200 & .002 \\
\hline Locality of school & .092 & .075 & .077 & 1.223 & .222 \\
\hline Complexity of school & .135 & .107 & .086 & 1.261 & .208 \\
\hline
\end{tabular}


Table 4.1

ANOVA of Time Management Practices Model - 1

\begin{tabular}{llccccc}
\hline Model & & $\begin{array}{c}\text { Sum of } \\
\text { Squares }\end{array}$ & Df & $\begin{array}{c}\text { Mean } \\
\text { Square }\end{array}$ & F & Sig. \\
\hline Time & Regression & 10.382 & 8 & 1.298 & 3.880 & $.000^{\mathrm{a}}$ \\
Management & Residual & 89.306 & 267 & .334 & & \\
Practices & Total & 99.689 & 275 & & & \\
\hline
\end{tabular}

Table 4.2

Summary of Time management Practices Model - 1

\begin{tabular}{llllllll}
\hline Model & $\mathrm{R}$ & $\begin{array}{l}\mathrm{R} \\
\text { Square }\end{array}$ & $\begin{array}{l}\text { Adjusted } \\
\text { Square }\end{array}$ & $\begin{array}{l}\text { Rtd. Error of the } \\
\text { Estimate }\end{array}$ & \\
\hline $\begin{array}{l}\text { Time Management } \\
\text { Practices }\end{array}$ & $.323^{\mathrm{a}}$ & .104 & .077 & .57834 & \\
\hline
\end{tabular}

To study the combined effect of the selected variables on principals' time management practices, consequently a standard multiple regression test was applied to identify the variables, which are the best predictors of principals' time management practices. The resultant $\mathrm{R}^{2}$ value (.104) indicates that variables other than those examined in this research (principal's age, principal's gender, principal's years of experience, training in time management area, school' level, school's type, school's location, and school's complexity) may be better predictors of time management practices. A brief examination of the standardized coefficient values for the independent variables in this research may also be of interest. As large beta values indicate, variables that make the strongest contribution to overall principals' time management practices are level of school (.207) and years of experience (.164) are the biggest contributors, whereas type of school (.075) and gender of the principal (.045) are the weakest. However, the significance value for level of school (.002), and years of experience (.025) indicates that their contribution to principals' time management is significant at the .05 level (See Table 3).

\section{Discussion}

The results indicated significant differences in two levels of school and have significant effect on principals' time management practices. Higher secondary school principals manage their time for different activities much better than secondary level school. The secondary 
education consists of two stages: the secondary and the higher secondary. Principals' time management behaviors could be different among principals with different personal characteristics or in different job settings (Claessens et al., 2007). Robertson's (1999) findings corroborate with results of this study; he found significant differences in the time management practices of middle and secondary school principals. Horng et al., (2010) see no notable difference in principals' time use based on the level of school (elementary, middle and high schools) and size of school. Principals in elementary schools and smaller schools report greater time management.

Gender of principals shows no significant difference and has no significant effect on principals' time management practices. Gender of principal has no significant effect on principals' time management practices. Horng et al, (2010) see no notable differences in principals' time use based on the principal's gender. Mansour (2011) established that gender of principals has no effect on effectively time management. Further he found that male principals are more paying attention in time management than female particularly at school level. Taylor (2007) found significant differences regarding time management of secondary school principals. Female principals spend more time on instructional leadership than male principals. These support the findings of this study. Robertson (1999) has also found no noteworthy differences in the time management practices between males and females principals. Grissom et al (2013) found that gender reveals significant differences for the time management measures. Male principals show lower time management scores than female principals. However, male principals show low score on short-range planning while they score more on delegation practices than female principals. Horng et al (2010) noted no notable differences in actions on the principal's gender in the use of time. Gorman (1993) found that instructional leaders must be effective and efficient time managers but effective managers were not necessarily instructional leaders. A number of researches derived similar significant results between males and females on time management practices (Glodt, 2006 \& Wells, 1993). Though, as the scores are so comparable, there comes into view to be slight point in practicing this more.

Years of administrative experience have significant effect on principals' time management practices. One would imagine that the more years of experience principals have higher time management practices they would use. Horng et al, (2010) found significant differences with principal's experience at their use of time. Robertson (1999) found that 
number of years of experience did not affect principals' time management practices.

Complexity of school has no significant effect on principals' time management practices. The result of this study affirmed that students' enrolment is not an important factor in management of time by principals. There was no significant difference in principals' time management with low, medium or high student' enrolment. Edorreh's (1989) research and results corroborate with findings of this study; he indicated that there was no significant difference in students' enrolment and their principals' allocation of time to task. Moreover, Allison and Mortiff's (1994) findings contradict findings of this study; the authors found students' enrolment to be a predictor of time usage by principals. However Burke's research (1980) does not correspond with findings of this study; the author found experience of the principals and school size to be predictors of time usage. The more complex the school, the less time management practices exhibited by the secondary school principals.

The study revealed that the location of schools has no significant influence on the principals' time management. It is probably because the school location either in rural or urban, did not affect skills of the principals' time management. Whatever the location, principals are required to apply their skills and experience, for achieving the best possible results. Akomolafe and Oluwatimehin (2013) also found no significant differences in principals' time management and location of school. The findings of this study do not corroborate with findings of Calabrese (1977) who found that school size, location and experience of principals affected their time utilization. The findings of Arubayi (1986) are not supportive of the findings of this study, owing to that the author found that a significant relationship between principals' time usage and school location.

Training in time management area has no significant effect on principals' time management practices. However, many researchers found that time management training is an indicator to increase an employee's perceived control of time (e.g. Macan, Shahani, Dipboye, \& Philips, 1990; Claessens et al., 2004), which in turn decreases work strain (e.g. Jex \& Elacqua, 1999), and increases job performance. The findings of this study resonates with Macan's (1994) research, who found that time management training of executives was not found to be effective. However findings of Hall and Hursch, (1982) and King, Winett, and Lovett (1986) suggest that training in time management resulted in an increased use of time management behaviours, which in turn led to outcomes that are more positive. 
Age has no significant effect on principals' time management practices. Ages of secondary school principals do not relate to the frequency of use of time management practices of school's principals (Robertson, 1999). Similarly, nature of school has no significant effect on principals' time management practices. The schools whether situated in urban area or in rural area have no influence on principals' time management practices.

\section{Conclusions}

It is concluded that significant differences were found between level of school and principals' time management practices. Higher secondary school principals exhibited the highest time management practices, while those secondary school principals exhibited the lowest. Whereas no significant differences in principals' time management practices have been found when the data were analyzed by locality and type of school. Level of school and administrative experience of school principals have significant effect on principals' time management practices. Whereas, principal's age, gender, training in time management area, school's nature, location, and complexity have no significant effect on principals' time management practices.

\section{Recommendations}

It is recommended that introductory courses, refresher courses, workshops, and seminars on time management practices should be included in in-service training program for principals to equip them with skills, knowledge and attitude on adequate time management practices. Building principals' time management capacities irrespective of gender, location, complexity and level of school may be a worthwhile strategy for increasing their focus on instructional leadership and pursuing school improvement. It is recommended that secondary school principals may be encouraged to receive training for the improvement of their time management practices. Indeed, several useful techniques and skills of time saving and effective utilization of time can be learned in simple and unsophisticated workshops. They may learn about how to schedule activities, prioritization of tasks, effective delegation process, how efficiently manage meetings, minimization of interruptions and managing paperwork. 


\section{Limitations of the Study}

This research is not without its shortcomings, as is the case with many other researches; the foremost being scope of the research methodology, the small sample size selection and the restricted geographic range; more research at provincial level or at the national level with a large sample is suggested. More significantly there are a number of environmental/ organizational issues which were not incorporated in this research, such as training in the area, leadership and management style, school complexity, and level of the school and location of school which have been related to principals' time management practices. These factors are suggested for in future research, to examine if there is any correlation between these factors and principals' time management practices.

\section{References}

Akomolafe, C. O. (2005). Principals' time management abilities in secondary schools in Nigeria. Nigerian Journal of Educational Administration and Planning, 5, 1-6.

Akomolafe, C. O. (2011). Time Resource Management. In; Management of Higher Education in Africa. Uyo, Nigeria. Abeam Publishing Co.

Akomolafe, C. O., \& Oluwatimehim, B. F. (2013). Principals' Time Management in Secondary Schools in Ondo State, Nigeria. Journals of Emerging Trends in Educational Research and Policy studies, 4(1), 13-16.

Allison and Mortiff (1994). Principals' time management and students discipline in secondary schools in Ondo State. M. Ed Thesis of University of Ado-Ekiti, Nigeria.

Amos, J. (1998). Managing your time. Oxford: How to Books.

Aquila, F. D. 2008. Time management tips for school administrators. Education Digest, 54: 37-39.

Arubayi, E. (1986). An investigation of secondary school principals' estimated time usage in Nigeria. A comparative analysis with V.S. Journal of research and Development in Education (19)2. 
Bittel, L. R. (1991). Right on time! The complete guide for timepressured managers. New York: McGraw-Hill.

Blendinger, J., \& Snipes, G. (1996). Managerial Behavior of a First-Year Principal. Retrieved from http://www.eric.ed.gov/ERICWebPortal/contentdelivery/servlet/ ERICServlet?accno=ED404726.

Bluedorn, A. C, \& Denhardt, R. B. (1988). Time and organizations. Journal of Management, 14, 299-320.

Botha, R. J. (2013). Time management abilities of school principals according to gender: a case study in selected Gauteng schools. Africa Education Review, 10(2), 364-380.

Britton, B. K. and Tesser, A. (1991). Effects of time-management practices on college grades. Journal of Educational Psychology, 83, 405-410.

Burke (1980). Time Resource Management: In Management of Higher Education in Africa. Uyo, Nigeria. Abaam Publishing Co.

Calabrese R. J. (1977). The Time Management Techniques of Indiana Secondary School Principals. Unpublished Doctoral Dissertation. Dissertation Abstract International.

Chase, et al., (2013). Time management for research productivity. Western Journal of Nursing Research. 35 (2), 155-176.

Claessens, B. J. C., Van Earde, W., Ruttee, C. G., \& Roe, R. A. (2007). A review of the time management literature. Personnel Review, 36, 255-276.

Claessens, B.J.C., Van Eerde, W., Rutte, C.R. and Roe, R.A. (2004), "Planning behavior and perceived control of time at work", Journal of Organizational Behavior, 25, 937-50.

Covey, S. R. (2009). The 7 Habits of Highly Effective People: Powerful Lessons in Personal Change.

Covey, S. R. 2009. Habits of highly effected leaders people (3rd revised edition).

Crouch, C. (2005). Getting organized: Learning how to focus, organize, and prioritize. Memphis, TN: Dawson Publishing. 
Edorreh, D. E. (1989). An investigation into the relationship between time usage and administrative effectiveness of principals in Bendel State. Unpublished Doctoral Dissertation, University of Benin.

Edwards, S.W. (1990). Time management and selected demographic factors of secondary school principals in Connecticut as predictors of job satisfaction. Doctoral dissertation, The University of Connecticut, USA).

Forster, M. 2006. Do it tomorrow and other secrets of time management. London: Hodder.

Forsyth, P. (1994). First things first. London: Pitman Publishing.

Glodt, K. (2006). A study of principals' perceptions of competence in common administrative roles. (Doctoral dissertation, Kansas State University, USA).

Goldring, E., Huff, J., May, H., \& Camburn, E. (2008). School context and individual characteristics: What influences principal practice? Journal of Educational Administration, 46 (3), 332-352.

Gordon, E. C. \& Borkan. S. C. (2014). Recapturing time: a practical approach to time management for physicians. Postgraduate Medical Journal, 90: 267-272.

Gorman, M.R. (1993). Time management strategies and the implications for instructional leadership of high school principals: A case study analysis. Doctoral dissertation, Widener University, USA.

Grissom, J. A., Loeb, S., \& Mitani, H. (2013). Principals time management skills: Explaining patterns in principals; time use and effectiveness.

Hager, J. (2006). How to gain discretionary time while on the job. Break out session presented at the 4th Annual Nevada Leadership Institute, Las Vegas, NV.

Hall, B. L., \& Hursch, D. E. (1982). An evaluation of the effects of a time management training program on work efficiency. Journal of Organizational Behavior Management, 3, 73-96.

Hallinger, P. \& Murphy, J. F. (2013). Running on Empty? Finding the Time and Capacity to 
Hemphill, B. (2002). Taming the paper tiger at home \& taming the paper tiger at work. Washington, D.C.: Kiplinger Books.

Hill, J. 1998. The importance of time management to principals. Thrust, 19: 37-39.

Horng, E. L., Klasik, D., \& Loeb, S. (2010). Principal's time use and school effectiveness. American Journal of Education, 116 (4), 491523.

Jex, J. M., \& Elacqua, T. C. (1999). Time management as a moderator of relations between stressors and employee strain. Work and Stress, 13, 182-191.

Kaufman, J. (2004). The last word of lateness. Good Housekeeping, 238, 41-43.

Kearns, H. \& Gardiner, M. (2007). Is time well spent? The relationship between time management behaviour, perceived effectiveness and work-related morale and distress in a university context. Higher Education Research \& Development, 26(2), 235-247.

Kennedy, C. (2002). The principal ship: Too much for one person? Principal, 82(1), 28-31.

King, A. C., Winett, R. A., \& Lovett, S. B. (1986). Enhancing coping behaviors in at-risk populations: The effects of time-management instruction and social support in women from dual-earner families. Behavior Therapy, 17, 57-66.

Larry, C. D. (2003). A study of time management use and preferred time management practices of middle and secondary school principals in selected southern states. (Doctoral Dissertation, University of Alabama, Birmingham, AL).Lead Learning. NASSP Bulletin, 97(1) 5-21.

Leboeuf, M. (2003). Essence of Time Management: Principles and Practice. Mumbai: Jaico Publishing.

Macan, T. H. (1994). Time management: Test of a process model. Journal of Applied Psychology, 79, 381-391.

Macan, T. H., Shahani, C., Dipboye, R. L. \& Philips, A. P. (1991). College Students' Time Management: Correlations With Academic 
Performance and Stress. Journal of Educational Psychology, 82(4), 760-768.

Mancini, M. (2003). Time management. New York: McGraw-Hill.

Mansour, I. M. (2011). The Effectiveness Degree of time management for high school principals and teachers at first secondary educational directorate in Amman. European Journal of Social Sciences, 25(3), 418-429.

Marshall, C., \& Hooley, R. (2006). The assistant principal: Leadership choices and challenges (2nd Ed). Thousand Oaks, CA: Corwin Press.

McCuen, R. H., (1996). The elements of academic research. New York: ASCE Press.

Miller, A. W. (2001). Finding time and support for instructional leadership. Principal Leadership, 2(4), 29-33.

Moroosi, P. 2007. Creating linkage between private and public: challenges facing women principals in South Africa. South African Journal of Education, 27(3): 507-521.

Mullins, L. J. (2005). Management and Organization Behaviour. $7^{\text {th }}$ Edition. United Kingdom: Pearson Education Limited. New York: Simon and Schuster.

Ojo, L. B., \& Olaniyan, D. A., (2008). Effective time management in organization Panacea or Placebo. European Journal of Scientific Research, 24(1), 127-133.

Portin, B. S., Shen, J., \& Williams, R. C. (1998). The changing principalship and its impact: Voices from principals. NASSP Bulletin, 82(602), 1-8.

Robertson, P. J. (1999). Time management practices of school principals in the United States. Ph. D, Dissertation, Virginia Polytechnic Institute and State University. (University Microfilms No.042199205455).

Schlenger, S., \& Roesch, R. (1989). How to be organized in spite of yourself: Time and space management that works with your personal style. New York: Penguin. 
Schriber, J. B. \& Gutek, B. A. (1987). Some time dimensions of work: measurement of an underlying aspect of organization culture. Journal of Applied Psychology, 72, 642-650.

Schuler, R. S. (1979). Managing stress means managing time. Personnel Journal, 58, 851-854.

Spillane, J. P., Camburn, E. M., Pareja, A. S. (2007). Taking a distributed perspective to the school principal's workday. Leadership and Policy in Schools, 6 (1), 103-125.

Spillane, J. P., Hunt, B. R. (2010). Days of their lives: A mixed-methods, descriptive analysis of the men and women at work in the principal's office. Journal of Curriculum Studies, 42 (3), 293-331.

Swart, A. J., Lombard, K., \& Jager, H. (2010). Exploring the relationship between time management skills and the academic achievement of African engineering students- a case study. European Journal of Engineering Education, 35(1), 79-89.

Tracy, B. (2004). Time power: A proven system for getting more done in less time than you even thought possible. New York: AMACOM.

Tracy, B. (2014). Time Management. New York: AMACOM.

Wells, G.A. (1993). Instructional management behavior, time management, and selected background variables of elementary school principals in Connecticut's urban school districts. Doctoral dissertation, The University of Connecticut, USA.

Received on: February 22, 2016

Revised on: May 19, 2016

Accepted on: June 03, 2016 